\title{
A Comparative Study of Distance Teaching in Elementary Schools Between China and the United States Under COVID-19
}

\author{
Cuiping Niu \\ ${ }^{1}$ School of Education, Yancheng Teachers' University, Jiangsu, China \\ Correspondence: Cuiping Niu, School of Education, Yancheng Teachers' University, Jiangsu, China. E-mail: \\ 786157908@qq.com
}

Received: June 20, 2021

Accepted: July 29, $2021 \quad$ Online Published: August 1, 2021

doi:10.5539/ells.v11n3p66

URL: https://doi.org/10.5539/ells.v11n3p66

\begin{abstract}
The outbreak and quick spread of COVID-19 quickly shut down almost all educational institutions in different parts the world by mid-March, 2020, presenting severe challenges to educators all over the world. The paper investigated the teaching situation of elementary schools in China and the United States during the epidemic period. The results show that the common challenges faced by the two countries in distance education are: 1) Elementary school students are young and have poor self-control ability, which requires close supervision and cooperation from parents; 2) Teachers' information technology level is limited, lack of network teaching ability. There are some problems in Distance Education in American elementary schools, such as parents can't urge students to study at home, digital technology inequality, low online attendance rate and so on, which further exposed the unfair problems in education. The problem of distance learning in elementary schools in China is that the learning resources are mainly subject knowledge, and the ability and methods of teachers to serve students' autonomous learning are insufficient. American distance learning experience is to make full use of the rich network learning resources and professional distance teaching platform, and pay attention to the cultivation of students' network autonomous learning ability. China's distance teaching experience is to give play to the advantages of centralized management, organize famous teachers to record high quality courses, establish the Air Classroom platform, and provide high-quality classroom teaching resources. Therefore, basic education institutions in both countries should strengthen the training of teachers' distance learning ability, improve the information-based teaching environment, learn from the experiences of both sides, and explore an effective mode of integrating online and offline education resources, so as to meet the challenges of basic education in the post epidemic era.
\end{abstract}

Keywords: epidemic situation, China, the US, basic education, distance teaching

\section{Introduction}

The outbreak and quick spread of COVID-19 quickly shut down almost all educational institutions in different parts the world by mid-March, 2020, presenting severe challenges to educators all over the world. Students in elementary schools can only receive distance education at home, which is unprecedented in China and the United States. How should schools carry out teaching activities under the epidemic situation? How do elementary schools in China and the United States organize distance learning? What is the effect of distance education? This paper investigates the teaching situation of elementary schools in China and the United States during the epidemic period, and compares and analyzes the experience and practice of distance teaching in the basic education stage of the two countries, so as to provide enlightenment for the modernization, informatization and intelligent reform of basic education in China, as well as how to deal with the crisis.

\section{Literature Review}

Distance learning, also called distance education, e-learning, and online learning, form of education in which the main elements include physical separation of teachers and students during instruction and the use of various technologies to facilitate student-teacher and student-student communication. After the outbreak and quick spread of COVID-19, distance learning has become main teaching mode. After the retrieval in Springer Link and VIP China Science and Technology Journal Database, we found 4,867 results for "distance learning COVID-19". Among all the researches of distance teaching under COVID-19, researchers paid attention to the value and challenges of distance teaching during the epidemic, the current situation of distance teaching in different 
schools, the development of teachers' professional ability under the epidemic, the mode and strategy of distance teaching, etc.

It was (Mahmoud Al-Balas, Hasan Ibrahim Al-Balas \& Hatim M. Jaber, 2020) who researched distance learning in clinical medical education amid COVID-19 pandemic in Jordan: current situation, challenges, and perspectives; Chenxue Yan, Shuke Yu and Rong Zhou (2021) argued online education is a double-edged sword. The epidemic situation has promoted the vigorous development of online education, but it also faces many challenges: the network environment in some areas is backward; the network equipment resources are insufficient; online platforms and network teaching resources are various; teachers are not proficient in information-based teaching; students are free to fly at home.

Some researchers (Chi-chung, Billy, \& Kent-man, 2021) compared advantages and disadvantages between distance learning and the conventional face-to-face approach conducted problem-based learning tutorial during the COVID-19 pandemic.

Gregory M. Francom (2021) investigated technologies, challenges and needs of K-12 teachers in the transition to distance learning during the COVID-19 pandemic.

\section{Research Design}

In this study, 141 school districts in Mississippi and 26 elementary schools in 13 cities of Jiangsu Province were selected as the research objects to understand the overall teaching methods during and after the outbreak of the epidemic. At the same time, in Jiangsu Province of China, 12 teachers and 24 students from $\mathrm{N}$ and $\mathrm{Y}$ elementary schools were selected as the online interviewees. In Mississippi, 12 teachers and 24 students from $\mathrm{M}$ and $\mathrm{C}$ elementary schools were selected as the online interviewees.

The interview questions are designed to be open-ended. According to the text data collected in the interview, this paper analyzes the distance teaching situation of elementary schools in the two countries in detail from the aspects of teaching methods, teaching platform, teaching plan, home learning content and online learning resources, teaching evaluation, etc.

\section{Results and Discussion}

During the outbreak of the epidemic, elementary schools in China and the United States chose distance learning. In the post epidemic period, most of Chinese elementary schools returned to traditional classroom teaching. According to the development of local epidemic situation, American elementary schools chose traditional classroom teaching, distance teaching and mixed teaching methods.

Table 1. Comparison of teaching methods in elementary schools between China and the US under COVID-19

\begin{tabular}{lllll}
\hline Teaching Methods & $\begin{array}{l}\text { Number of American } \\
\text { schools }\end{array}$ & $\begin{array}{l}\text { Proportion in total } \\
(\%)\end{array}$ & $\begin{array}{l}\text { Number of schools } \\
\text { in China }\end{array}$ & Proportion in total (\%) \\
\hline T & 8 & 5.7 & 22 & 84.62 \\
H & 19 & 13.46 & 0 & 0 \\
V & 24 & 17.02 & 4 & 15.38 \\
TV & 40 & 28.36 & 0 & 0 \\
HV & 27 & 19.15 & 0 & 0 \\
THV & 23 & 16.31 & 0 & 0 \\
SUM & 141 & 100 & 26 & 100 \\
\hline
\end{tabular}

Note. T stands for traditional offline teaching, $\mathrm{V}$ stands for virtual teaching, $\mathrm{H}$ stands for hybrid online and offline alternative mixed teaching.

As we see in Table 1, as the epidemic situation in China has eased, $84.62 \%$ of the schools have chosen the traditional offline teaching method and $15.38 \%$ of the schools chose virtual teaching method. While the epidemic situation in the United States has not been effectively controlled, so the schools have chosen a variety of teaching methods. Although most of schools in China reopened during the period of epidemic alleviation, due to the global epidemic, distance learning has become an important way for schools to cope with the challenges of the epidemic. Next, we will focus about distance learning in the two countries. 


\subsection{Distance Teaching Mode and Teaching Platform}

Table 2. Teaching mode and platform used in Distance Teaching of elementary schools in China and the US

\begin{tabular}{lll}
\hline Countries & Distance Teaching Mode & Distance Teaching Platform \\
\hline The US & Live teaching & Canvas/ Seesaw/ Google Classroom/Zoom \\
& Recording and broadcasting teaching & Edgenuity/ iReady/ ClassDojo \\
China & Live teaching & QQ/Air Class taught by famous teachers \\
& Recording and broadcasting teaching & CCtalk/ DingTalk \\
& Massive Open Online Course & \\
\hline
\end{tabular}

In Table 2, Both China and the United States adopt the combination of live teaching and video teaching in distance teaching. In contrast, several distance learning platforms adopted by American elementary schools are more mature in technology and more complete in function. These platforms can meet the needs of virtual classroom, course management, data sharing, homework test, group discussion and other distance teaching. For instance, Canvas is the open, extensible LMS built to amplify teaching and maximize learning. Teachers can communicate with individual students, groups, the entire class, or even parents through messaging, audio notes, video, and more. And students can collaborate among themselves via chat group, video, and other messaging tools. Zoom is the leader in modern enterprise video communications, with an easy, reliable cloud platform for video and audio conferencing, chat, and webinars. Besides, Zoom is compatible with Windows, macOS, iOS, Android, Chrome OS, and Linux. It is noted for its simple interface and usability, regardless of technological expertise.

Although the distance teaching platform adopted by elementary schools in China is relatively simple, due to the advantages of centralized management, the Chinese government can quickly organize famous teachers of different disciplines to record excellent courses and establish Air Classroom platforms. In China, most of education management departments all over the country provide Air Classroom platform for distance learning. The videos are recorded by famous teachers. Students can register and log in for online learning.

\subsection{Distance Teaching Plan}

Table 3. Virtual schedule of Grade three of N elementary school in Jiangsu Province

\begin{tabular}{|c|c|c|c|c|c|}
\hline Time & Monday & Tuesday & Wednesday & Thursday & Friday \\
\hline \multirow[t]{2}{*}{ M: 9:30-9:50 } & Chinese & Chinese & Chinese & Chinese & Chinese \\
\hline & Reading and Writing & Finish Worksheet & Reading and Writing & Have air class on APP & Finish Worksheet \\
\hline \multirow[t]{4}{*}{ M: 10:30-10:50 } & Eye exercises & & & & \\
\hline & English & Information & Math & English & Math \\
\hline & & Technology & & & \\
\hline & Unit 8 & & $\begin{array}{l}\text { Addition and } \\
\text { subtraction }\end{array}$ & Unit 9 & $\begin{array}{l}\text { Calculation } \\
\text { Have air class on APP }\end{array}$ \\
\hline \multirow[t]{2}{*}{$P: 2: 00-2: 30$} & Math & Math & Science & Math & Music \\
\hline & $\begin{array}{l}\text { Understanding of } \\
\text { decimals }\end{array}$ & Finish Worksheet & Plant & Have air class on APP & Have air class on APP \\
\hline P: $3: 00-7: 00$ & Free Time & & & & \\
\hline P: 7:00-7:20 & English online Q \& A & Math online Q \& A & Chinese online Q \& A & English online Q \& A & Chinese online Q \& A \\
\hline
\end{tabular}

Table 3 shows the online teaching schedule of Grade 3 in $\mathrm{N}$ elementary school. It can be seen from the teaching schedule that Chinese, mathematics, and English courses are available every day, and music, labor skills, art and other courses are 1-2 sessions a week. The teaching schedule is detailed and specific. 


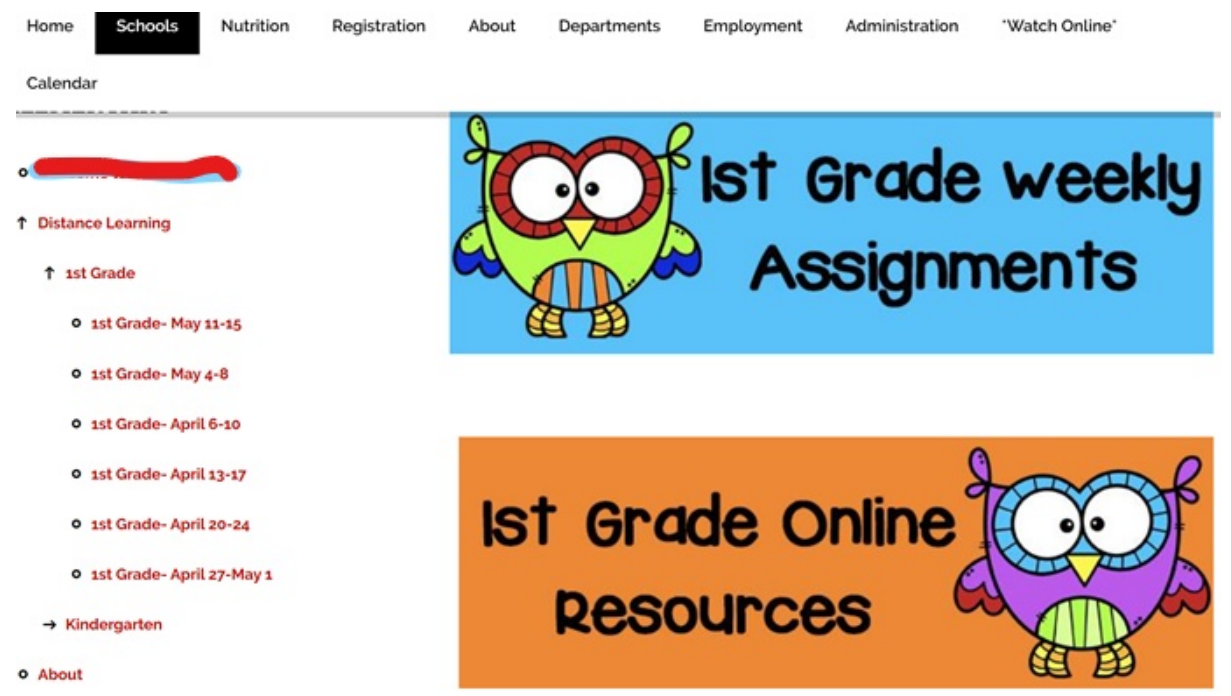

Figure 1. M elementary school website: distance learning instruction page

According to the survey results, M public elementary school did not show helplessness in the face of the sudden outbreak emergency. The state government and school emergency plans were worked out very timely, and the weekly learning plan was timely and orderly promoted. Materials for distance learning were packaged and sent in advance every week by the school's official website and the teacher in charge of the class. As Figure 1 shown, students and parents can directly access distance learning resources by opening the school website.

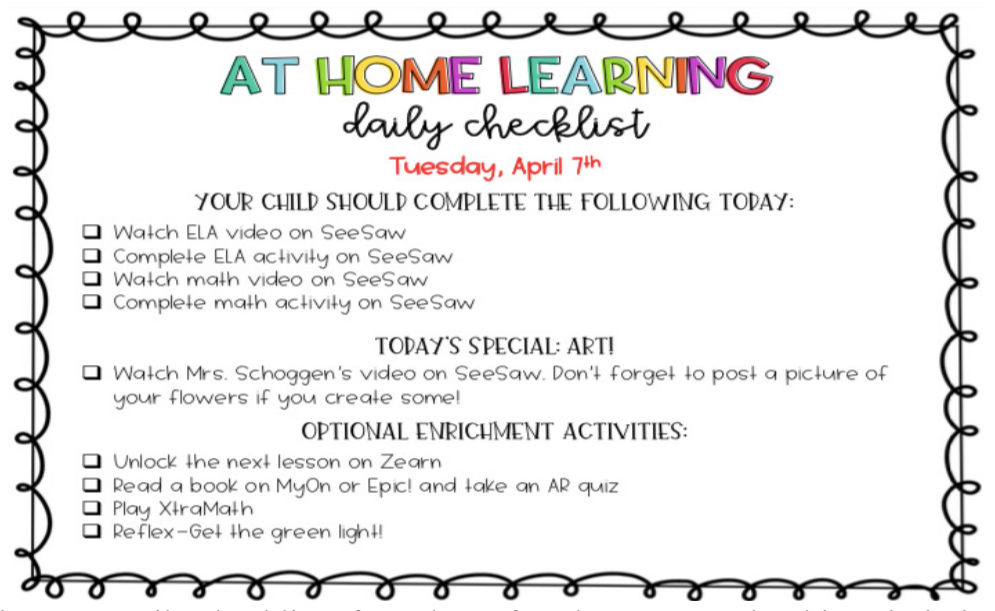

Figure 2. Daily checklist of Grade 2 of C elementary school in Mississippi

In Mississippi, teachers send the daily checklist to the email address registered by the parents in advance every morning. Figure 2 shows the learning tasks that sophomores need to complete at home on Tuesday. The task list module from Monday to Friday is the same, but the difference is the special homework part every day.

From the distance teaching plan of the two elementary schools, the teaching schedule of $\mathrm{N}$ elementary school is specific and detailed, which has clear and specific arrangements for the time of teachers' remote teaching live broadcast and students' home learning videos. Although the teaching schedule of $\mathrm{C}$ elementary school does not list the specific teaching time, it also reflects the principle of teaching students in accordance with their aptitude. The daily "OPTIONAL ENRICHMENT ACTIVITIES" part reflects the respect for students' personalized learning differences. This is mainly because distance teaching in elementary schools in China is mainly based on teachers' live teaching and Air Classroom, and the teaching mode still follows the strict work and rest time in daily teaching. While distance teaching in elementary schools in the United States is based on various online education software, teachers are more in the role of organization and arrangement. 


\subsection{Home Learning Contents and Online Learning Resources}

During the epidemic period, the school is not so much carrying out distance learning as providing learning guidance and learning resources for students' home-based learning. During the closure period of American elementary schools, the content of distance learning is mainly the learning resource package issued by the school. Students' home learning is mainly through various online learning websites or apps, and teachers only conduct live teaching once a week. In the post epidemic period, American elementary schools provide students who choose distance learning with not less than three hours of live teaching every day in addition to various online learning websites.

During the closing period of elementary schools in China, distance learning relies on the Air Classroom, and students' home learning content is mainly in accordance with the school curriculum in the Air Classroom to complete their homework.

Table 4. Distance learning contents at home and online resources

\begin{tabular}{|c|c|c|c|}
\hline countries & subject & Learning Contents at Home & Online Resources \\
\hline \multirow[t]{23}{*}{ The US } & \multirow[t]{4}{*}{ Reading } & Learn with teacher's video & ABC Mouse \\
\hline & & Finish home learning activities on the worksheet & Razkids \\
\hline & & Finish Reading test on APP & Sight Word Ninja \\
\hline & & Learn using online resources & Starfall \\
\hline & \multirow[t]{4}{*}{ ELA } & Read for 20 minutes daily, & Freckle, \\
\hline & & Morning Work, & MyON, \\
\hline & & Finish Comprehension on the worksheet, & EPIC! \\
\hline & & Study Island ELA & Study Island (ELA Skills Practice) \\
\hline & \multirow[t]{4}{*}{ Math } & Finish home learning activities on the worksheet, & ZEARN, \\
\hline & & Unlock lessons on Zearn/Finish activities on Seesaw & Reflex Math, \\
\hline & & Study Island Math & Freckle, \\
\hline & & & Study Island (Math Practice) \\
\hline & Writing & Finish Journals & \\
\hline & \multirow[t]{2}{*}{ Art } & Learn with teacher's video, & artisandesarts.blogspot.com \\
\hline & & Do art activity with teacher's instructions & other art websites \\
\hline & \multirow[t]{2}{*}{ Music } & move with a Go Noodle video; review songs learned at school; & YouTube \\
\hline & & watch music video and sing/draw & $\begin{array}{l}\text { Go Noodle Videos App } \\
\text { other music website }\end{array}$ \\
\hline & \multirow[t]{2}{*}{ PE } & Physical activity & YouTube \\
\hline & & Health activity & Kidhealth.org \\
\hline & \multirow[t]{4}{*}{ Library } & Read a book and answer questions & www.funbrain.com \\
\hline & & Finish activities related to the book & www.storylineonline.net \\
\hline & & & Scholastic \\
\hline & & & YouTube \\
\hline \multirow[t]{12}{*}{ China } & \multirow[t]{3}{*}{ Chinese } & Learn with teacher's video & Air class of famous teachers in \\
\hline & & Have Air Class & Jiangsu Province \\
\hline & & Finish homework & Nanjing online school APP \\
\hline & \multirow[t]{3}{*}{ Math } & Learn with teacher's video & Zhixue.com \\
\hline & & Have Air Class & \\
\hline & & Finish homework & \\
\hline & \multirow[t]{3}{*}{ English } & Learn with teacher's video & \\
\hline & & Have Air Class & \\
\hline & & Finish homework & \\
\hline & PE & Learn with teacher's video & \\
\hline & Music & Have Air Class & \\
\hline & Science & Finish homework & \\
\hline
\end{tabular}

Note. Reading courses of Library and Reading are different. When there's no pandemic, students go to the school library to read books at a fixed time every day. During the pandemic period, students still need to $\log$ in the website provided by teachers to complete the assigned reading materials every week.

It can be seen from Table 4 that American elementary schools offer a wide range of courses and rich online learning resources. Each course has its own professional online learning app. For instance, Epic! is a digital 
library, which provides thousands of books, videos and quizzes from leading publishers to help kids everywhere read, learn and grow. ZEARN is a math learning website, which makes math engaging and accessible for all learners. In contrast, there are few professional e-learning apps for different disciplines in China, which is not conducive to students' autonomous learning at home.

\subsection{Students Learning Styles at Home}

In order to further understand how students studied at home, the author conducted a network survey, together with case observation, and made statistics according to the frequency of adopting these learning methods within a week.

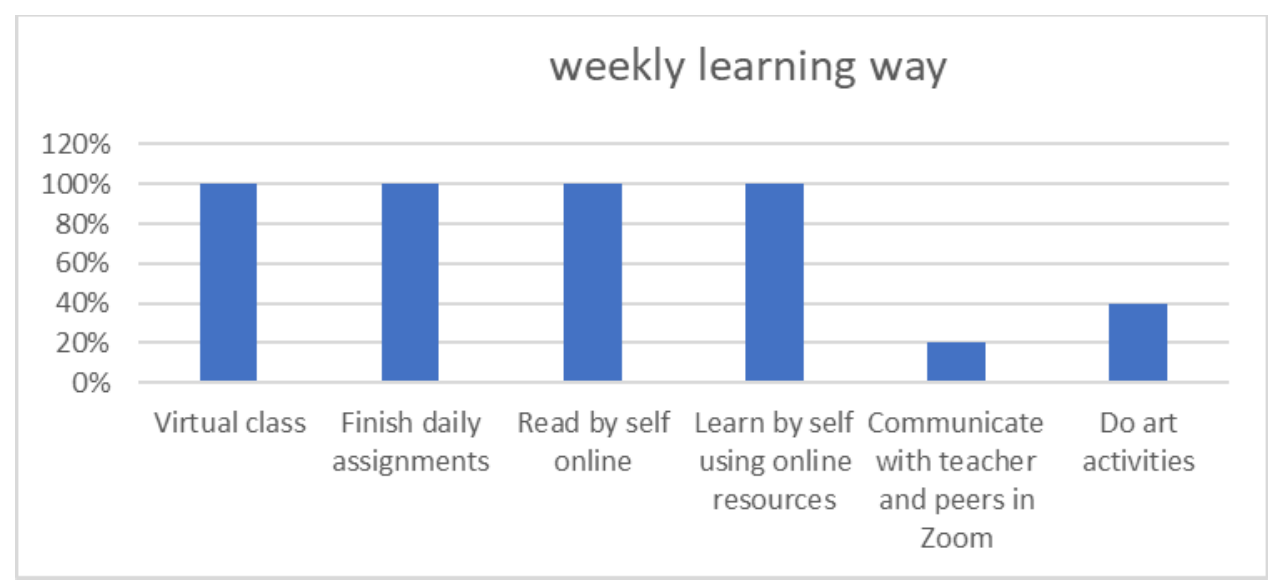

Figure 3. American students' weekly learning ways at home

It was found that American students mainly used the seven learning styles listed in Figure 3 to complete the learning tasks at home. Online classes, online homework, AR reading activities on the Internet and network teaching games (mainly mathematical games) are among the most frequently used learning ways in their daily study. Every Wednesday afternoon there would be classes with other students through Zoom and two drawing classes every week. Three days in a week would be settled for games with teachers through video.

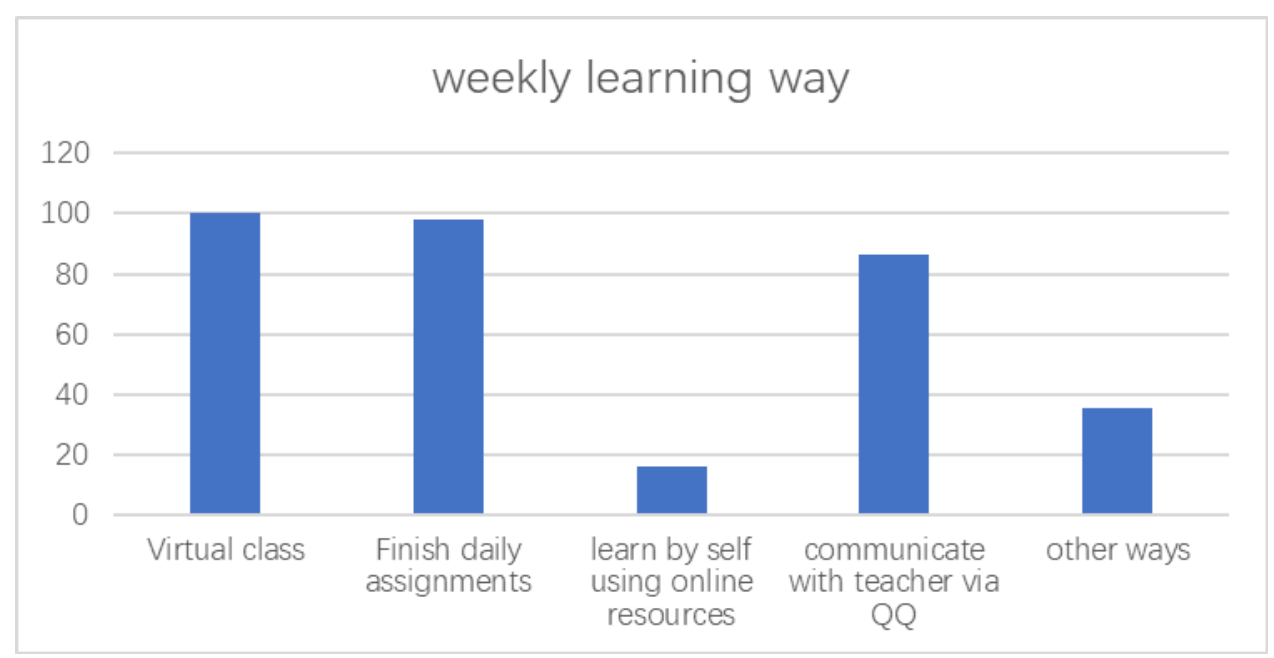

Figure 4. Chinese students' weekly learning ways at home

As Figure 4 shows, Chinese students mainly used the five learning styles at home. Having virtual class, finish daily assignments and communicate with teacher via QQ are their mainly learning ways at home.

Of course, here mentioned are the learning styles that the students adopt when they complete the learning tasks assigned by the school. Individually, the learning styles are not the same. Taking the case observed by the author 
as an example, one of the children drew pictures almost every day because he likes painting activities.

\subsection{Distance Teaching Evaluation}

Teaching evaluation is the key to the effect of distance education. Since Jiangsu Province is the first time to carry out such a long-distance teaching in elementary school, there is no systematic teaching evaluation mechanism, nor does it use the professional distance teaching platform to collect and correct students' homework. Homework layout, inspection and the understanding of students' learning situation are mainly through the class QQ group.

Table 5. Scoring standard of Distance Education of M elementary school

\begin{tabular}{|c|c|c|}
\hline Grade & ELA & Math \\
\hline \multirow[t]{6}{*}{ G2 } & $0-10 \%=0$ points & $0-10 \%=0$ points \\
\hline & $11-28 \%=2$ points & $11-28 \%=2$ points \\
\hline & $29-46 \%=4$ points & $29-46 \%=4$ points \\
\hline & $47-64 \%=6$ points & $47-64 \%=6$ points \\
\hline & $65-82 \%=8$ points & $65-82 \%=8$ points \\
\hline & $83-100 \%=10$ points & $83-100 \%=10$ points \\
\hline \multirow[t]{6}{*}{ G3 } & $0-13 \%=0$ points & $0-13 \%=0$ points \\
\hline & $14-31 \%=2$ points & $14-30 \%=2$ points \\
\hline & $32-47 \%=4$ points & $31-47 \%=4$ points \\
\hline & $48-64 \%=6$ points & $48-67 \%=6$ points \\
\hline & $65-81 \%=8$ points & $68-83 \%=8$ points \\
\hline & $82-100 \%=10$ points & $84-100 \%=10$ points \\
\hline
\end{tabular}

As Table 5 shown, there is a special system guarantee for distance teaching evaluation in M elementary schools, which stipulates that nine weeks is a scoring cycle. In the ninth week, according to the progress of students completing tasks on seesaw platform, students will be given feedback points. If students put the completed paper exercise books in the box at the door of the school office, they will also get two extra points.

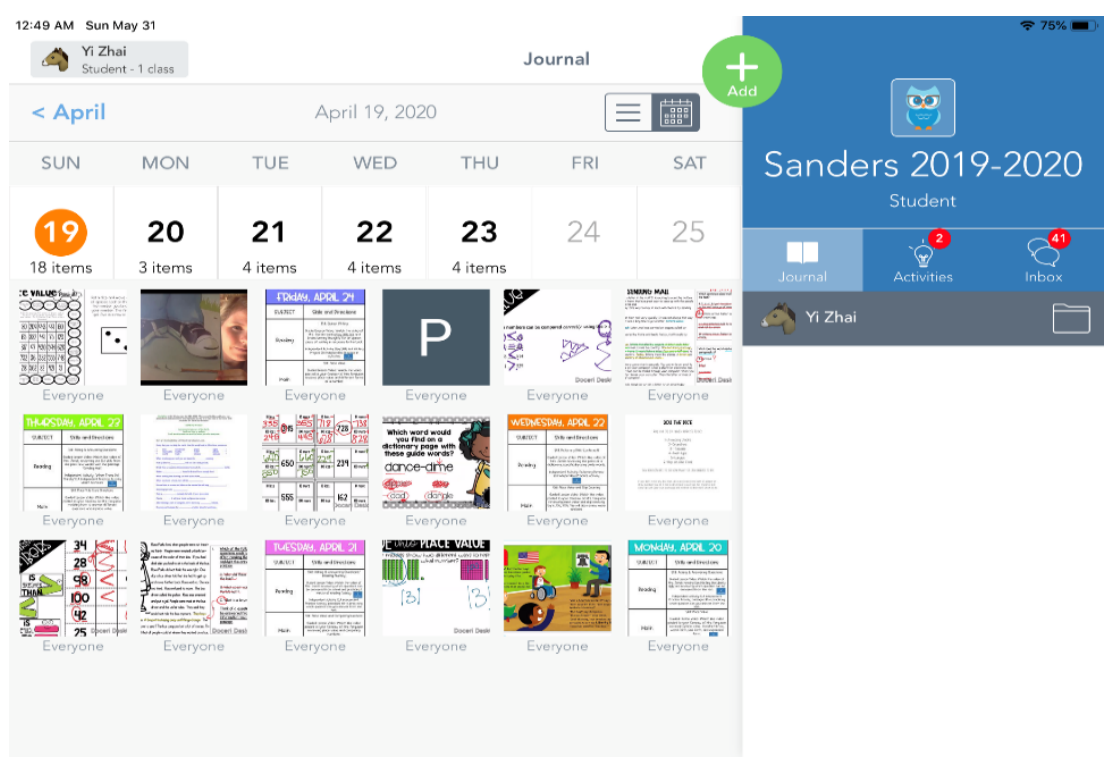

Figure 5. Homework uploaded by a sophomore on seesaw platform 


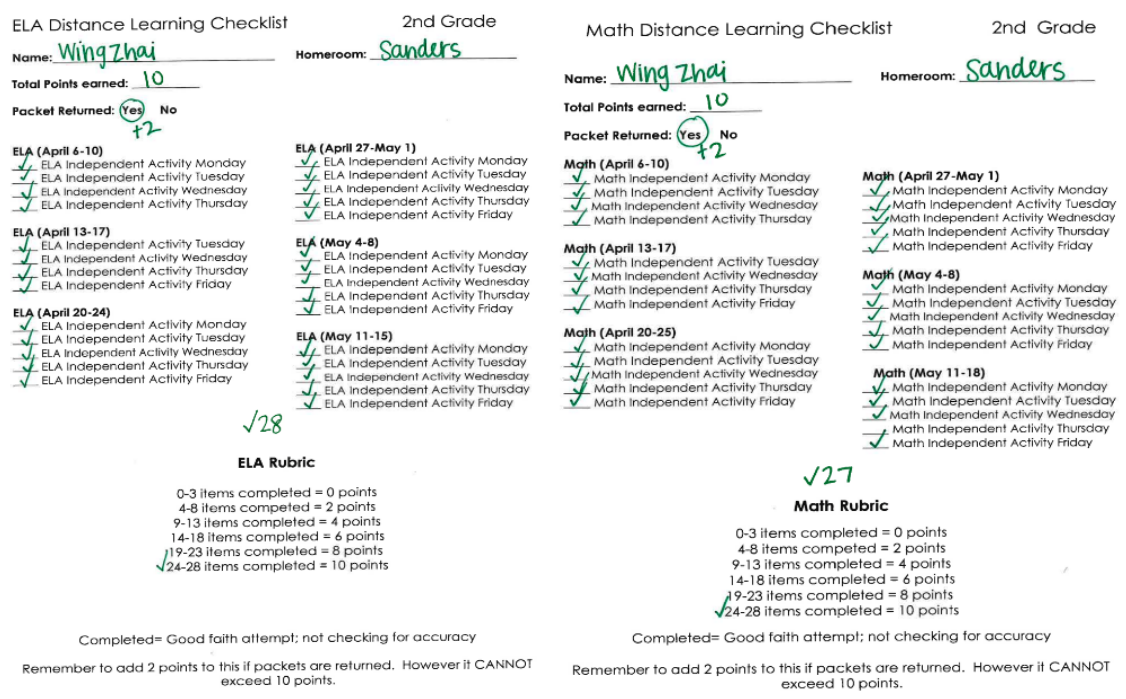

Figure 6. Distance learning performance evaluation form of a sophomore

Besides, American elementary school students receive daily tasks given by teachers through seesaw platform, learn live videos (videos cover mathematics, art, language, music, sports and other disciplines), and then publish their homework (or works) on the platform. Teachers review students' homework or show some good works in the whole class through the platform. Figure 5 shows all the learning tasks uploaded by a student on seesaw platform from April 19 to 23. Students can log in at any time to see their homework and teacher's correction. The student uploaded course content includes composition, reading comprehension exercises, math exercise, songs or audio of musical Instrument playing, handwork pictures, painting pictures and video of daily interesting activities, etc. From the learning tasks completed on the Seesaw platform we can have a general idea about his learning ways at home. Figure 6 is the final teacher's distance learning performance evaluation form.

\section{The Common Challenges Faced by the Two Countries}

\subsection{Elementary School Students Are Young and Have Poor Self-Control Ability, Which Requires Close Supervision and Cooperation from Parents}

Different from college students, elementary school students have poor self-control ability and weak self-learning ability. During the period of home-based learning, whether we can complete the home-based learning tasks assigned by teachers and $\log$ in to the distance learning platform to participate in distance learning activities depends largely on the supervision of parents. Among the 24 Chinese parents interviewed, $62.5 \%$ of the parents can assist their children's home-based learning, and $45.83 \%$ of the grandparents can supervise their children's home-based learning. Nevertheless, $100 \%$ of Chinese parents complained that it took too much time and energy to urge their children to carry out distance education, and $70.83 \%$ worried that the use of electronic devices would lead to the decline of their children's eyesight. However, $75 \%$ of American parents were unable to urge their children to study at home because they still had to work during the epidemic period, and only $20.83 \%$ of American grandparents could provide help to urge their children to complete the task of studying at home.

\subsection{Teachers' Information Technology Level Is Limited, Lack of Network Teaching Ability}

Influenced by COVID-19, long time distance education is needed in the basic education stage. Neither country nor China has precedent. $91.67 \%$ of Chinese teachers only use PPT and other simple multimedia technology, $83.33 \%$ of them can't use video recording and broadcasting software, and $87.5 \%$ of them have never used Ding Talk and other distance teaching platforms. $41.66 \%$ of American teachers indicated that they lacked experience in using canvas, zoom and other teaching platforms, and $25 \%$ of them were not proficient in using video recording software.

\section{Problems in Distance Learning in American Elementary Schools}

\subsection{Lack of Effective Supervision from Parents and Low Online Attendance Rate}

Due to the impact of the epidemic, parents are facing unemployment and economic problems, and $75 \%$ of American parents have no time to urge their children to study. In addition, there is no tradition of grandparents helping to take care of children in the United States. Therefore, some families have poor home-based learning 
effect. In the first week of distance education, the online attendance rate of elementary school students is less than $20 \%$.

\subsection{Digital Divide Makes the Problem of Education Inequity More Prominent}

Although $\mathrm{M}$ and $\mathrm{C}$ elementary schools in Mississippi allow students to take their school IPAD home during home study, many poor students are unable to participate in online learning due to lack of Internet connection at home. According to the latest survey data of American Pew Research Center, a quarter of households in the United States do not have broadband network. Educators at the University of California, Berkeley have observed that in the process of carrying out comprehensive online education, the inequality of digital technology resources will aggravate the inequality of educational opportunities and effects, and further widen the gap between the rich and the poor.

\subsection{The Quality of Distance Teaching Is Affected by the General Subject Teaching in Elementary Schools}

Elementary school teachers in the United States teach all subjects, and they teach different subjects online for their students every day. In the process of online teaching, there is a greater amount of lesson preparation. Therefore, they can only choose one or two subjects and give up other subjects. Some teachers are busy preparing various learning materials for students, so they can only choose simple teaching methods when teaching live online, such as reading a story, leading students to write a few words or guiding students to complete their homework. Although some elementary schools divide online live teaching into group teaching to improve the quality of online teaching, for example, a class is divided into six groups with 4-5 students in each group, group teaching is a mere formality. The group teaching time is 15 minutes according to the plan, but the actual teaching time is only 5-10 minutes, and teachers seldom have in-depth communication with students.

\section{Problems in Distance Teaching in Chinese Elementary Schools}

\subsection{The Main Learning Resources Are Subject Knowledge}

Among the learning resource platforms provided by Jiangsu Provincial Department of education and elementary schools, $82.5 \%$ of the online resources are subject knowledge teaching and review guidance, followed by music, sports and Fine Arts (7.3\%), moral education and Practice (4.1\%) and interdisciplinary learning (1.6\%). This shows that online learning resources are mainly subject knowledge, and other areas of education and interdisciplinary learning resources are slightly insufficient. In the online teaching, teachers mainly arrange homework and review textbook knowledge points.

\subsection{The Ability and Method of Teachers Serving Students' Autonomous Learning Are Insufficient}

In the interview, $83.33 \%$ of the teachers said that they did not know how to guide students' autonomous learning in distance teaching, and they still focused on Teaching in distance teaching. They equated distance teaching with PPT playing dubbing explanation, and interactive communication with students with online answering questions or correcting homework. Moreover, China "overemphasizes subject teaching as the center in the construction of online education resources, and many resources are simple 'electronic textbooks' which simply scan or input the contents of textbooks directly." Therefore, the network education platform cannot provide teachers and students with the function of teaching and active learning, and cannot carry out personalized learning evaluation through the network.

"Online teaching is a semi open education and teaching activity centered on platform and resources. Here, classes and courses are no longer the most important, class hours and credits are no longer important, even schools and majors are no longer important. What matters is what I have learned, shared and created. The key factor affecting online teaching is not the teachers, but the students. Students' autonomy, self-discipline and online learning ability are the primary factors to ensure the quality of online teaching. What teachers can do and most need to do is to fully mobilize students' learning motivation and enthusiasm through high-quality teaching design. The most important ability of online teachers is online instructional design ability, followed by online teaching ability". It can be seen that learning in the information network era emphasizes students' autonomous learning rather than teachers' knowledge transfer.

\section{American Experience in Distance Teaching}

The United States can make full use of the rich network learning resources and professional distance teaching platform in distance teaching, and pay attention to the cultivation of students' network autonomous learning ability.

The US attaches great importance to the role of information technology in basic education. From 1996 to 2016, the US Federal Department of Education issued the National Educational Technology Plan (NETP) for five 
consecutive times. Under the promotion of the government, online education in the US has been popularized in the field of basic education. According to statistics, "In 2000, 97\% of the elementary schools in the United States had Internet access, while $100 \%$ of the middle schools had Internet access. In $2003,100 \%$ of the elementary schools had Internet access."

With its foundation and advantages in network technology, the United States has developed abundant network learning resources, which provides convenient conditions for the smooth development of distance learning. During the pandemic, the schools selected more than ten online learning platforms for students, most of which have purchased registration. Students only need to $\log$ in the account and password provided by the school to get a large number of high-quality learning resources. Among them, Seesaw, MyON and Zearn are all online platforms for reading, mathematics and other courses normally used by schools. In particular, the Seesaw online platform can automatically record the learning history data of each student, so it is the main platform for teachers and students to conduct distance teaching and learning during the pandemic.

In addition, students of $\mathrm{M}$ and $\mathrm{C}$ schools often use Myon, Zearn, Epic! and other online learning platforms at school. Most of students of G2 to G5 can $\log$ in the website independently, receive the tasks assigned by the teacher, search the materials they need, scan and upload their handmade works and drawing works. The network independent learning ability benefits from the personalized learning design of the network platform, and the cultivation of students' ability to use information.

\section{Chinese Experience in Distance Teaching}

China can give play to the advantages of centralized management in distance teaching, organize famous teachers to record high-quality courses, establish famous teachers' aerial classroom platform, and provide high-quality classroom teaching resources. After the outbreak of COVID-19, Jiangsu province organized 2000 teachers in the province to record 6100 excellent courses, providing quality education and teaching resources for 12 grades of elementary school and middle school, covering $60 \%$ of the subjects in the compulsory education stage, and the total website visits reached 7 million 815 thousand times during the epidemic period.

Besides, Chinese teachers can check students' home learning situation through QQ group every day, and give timely feedback to students' learning problems.

\section{Suggestions}

\subsection{Integrative Quality Teaching Resources to Improve the Efficiency of Distance Teaching}

Schools should give full play to the advantages of distance teaching, break the class teaching form, make overall planning according to the grade, collect wisdom of excellent teachers to record excellent teaching lessons, and open them to all grade students, especially for American schools. For example, all 1st grade teachers may work together to complete the explanation of different parts of the course, and then upload to Seesaw platform for students to $\log$ in for learning. Teachers of relevant courses may arrange online learning tutoring for students at a fixed time every day according to different disciplines. This saves teachers' time and allows them to spend more time on preparing teaching videos and completing online supervision and tutoring of students, instead of leaving the supervision of learning tasks to parents.

\subsection{Conduct Separate Offline Teaching in Small Groups}

As people return to work, schools are reopened again. To avoid further spread of the pandemic, schools can conduct face-to-face teaching in groups and isolation. Instead of the original class model, students arrive at school in groups, at a social distance or face to face wearing masks. Of course, we can also investigate the students' situation and arrange the offline teaching flexibly. For students whose parents are unable to guide them at home or whose ability to study at home is poor, offline group teaching can be adopted. However, students with strong autonomous learning ability and parents at home can still adopt distance learning. This will reduce the number of students attending school, which will be possible to teach in isolation and focus on the realities of different families.

\subsection{Arrange the Proportion of Offline Teaching Time and Online Teaching Time by Subjects}

According to the teaching characteristics of different subjects, some subjects need more interaction between teachers and students, so more offline teaching time can be arranged. For example, although reading, mathematics and writing are the main courses of the school, these subjects can be completed through online teaching. While arts, music and physical education courses require more on-site guidance from teachers to keep abreast of students' learning situation, so more offline teaching time can be arranged. 


\subsection{Increase the Frequency of Students' Online Interaction}

The role of a school is not only to impart knowledge and promote the development of students' abilities, but more importantly, it is to provide a place for teachers and students to interact and communicate with each other, which will be conducive to the healthy development of students' society. Affected by the virus, however, in the case of only maintaining social distance, schools can increase interaction frequency between teachers and students through Zoom. To change zoom class meeting once a week time to once a day or two days, build up class communication group, and arrange peer video chat as a part of daily work.

All in all, the basic education institutions of both countries should strengthen the training of teachers' distance teaching ability, improve the information-based teaching environment, learn from the experience of both sides, and explore an effective mode of integrating online and offline education resources, so as to meet the challenges of the post epidemic era to the information-based reform of basic education.

\section{Acknowledgements}

Funded by "key project of higher education in the 13th five year plan of Educational Science in Jiangsu Province" (rant number: B-a/2020/01/14).

\section{References}

Bliame, H., \& Kohli, S. (2020). 15,000 L. A. high school students are AWOL online, 40,000 fail to check in daily amid coronavirus closures. Los Angeles Times. Retrieved April 16, 2020, from https//www.latimes.coim/californm/story/2020-03-30/coronavirias-los-angeles-schools15000-high-school-st udents-absent $4 /$

Cao, W. Z. (2007). A comparative study on the integration of online education resources between Chinese and American primary and secondary schools. E-education Research, 168(4), 29.

Clinton public school district. (2021). Distance Learning Resources provided by C elementary school. Retrieved from https://www.clintonpublicschools.com/

Distance teaching evaluation score table. Retrieved from https://www.madisonpublicschools.com/cms/lib/MS01001946/Centricity/Domain/53/Distance\%20Learning $\% 20$ Grading\%20Plan\%20for\%20Parents

Hu, Y. B., \& Long, T. T. (2017). The current situation and Enlightenment of basic education informatization in the United States. China Educational Technology, 362(3), 23.

Jiangsu education department. (2021). Air class recorded by famous teachers in Jiangsu Province. Retrieved from http://jyt.jiangsu.gov.cn/

MDE District Restart and Recovery Plan Summary. (2020-2021). Retrieved from https://www.mdek12.org/sites/default/files/Offices/MDE/OCGR/restart_recovery_responses_2020.08.05_4 30p_20226.pdf

The famous teacher of Jiangsu Province is coming. Retrieved from https://www.sohu.com/a/339944582_120207615

Wang, Z. L. (2020). How should education transform in the post epidemic era. E-education Research, 324(4), 15.

\section{Copyrights}

Copyright for this article is retained by the author, with first publication rights granted to the journal.

This is an open-access article distributed under the terms and conditions of the Creative Commons Attribution license (http://creativecommons.org/licenses/by/4.0/). 